\title{
Android-Based Educational Games as Media for Children to Learn Nusantara Musical Instruments
}

\author{
Afiin Fitri Millatin ${ }^{1}$, Sutiyono $^{2}$, Sri Wahyuni Syukur ${ }^{1}$ \\ ${ }^{1}$ Graduate School of Arts Education, Yogyakarta State University, Yogyakarta, Indonesia \\ ${ }^{2}$ Graduate School, Yogyakarta State University, Yogyakarta, Indonesia \\ *Corresponding author. Email: millatinafiin@gmail.com
}

\begin{abstract}
This research was carried out using the ADDIE model development method (Analysis, Design, Development, Implementation, Evaluation). In this postmodern era with rapid technological developments and the phenomena of online schools due to the Covid-19 pandemic, the researchers developed Android-based game learning media to improve the learning interests of children about Indonesian musical instruments in the form of puzzle games. However, this development research was only conducted in three stages: ADD (Analysis, Design, Development). The learning media development process started from the analysis stage, which was to analyze the needs of child learning methods, and the hardware and software used. The second stage, design, made the storyboard, pictures, menu buttons, and the background. The third stage, development, is the realization of the product design in which the sample of Nusantara (Indonesian) musical instruments was made using a Corel Draw X4 application and then converted into android-based games using the Appsgeyser application. The application has been assessed by media validators and designs from IT Consultant Phicos Group, Mr. Bayu Antrakusuma, M.Pd. The results show that although the research was only up to the development stage, the learning media could still be continued to the next stage through revisions until the product was claimed appropriate to implement by the media experts and practitioners, and an evaluation stage could be carried out.
\end{abstract}

Keywords: Learning media development, Android-Based Educational Games, Nusantara Musical Instruments

\section{INTRODUCTION}

The world of children is a play world, so learning should be managed fun with playing while learning techniques. In the Indonesian Dictionary, playing can be interpreted as doing something to please the heart (using certain tools or others). Playing for children with an age range of 3-6 years is a significant activity. We need to admit that playing while learning is an effective and efficient activity for children to understand the materials. In addition, Sofia Hartati [4] said that playing is an essential means of social, emotional, and cognitive development of children and can reflect child development.

In the era of information technology development, education for children also faces significant challenges. If a game is considered part of education, digital technology's current development has introduced various types of virtual games and become part of children's lives. Children born in the early $21^{\text {st }}$ century are likely to know android-based games through their parents' cell phones; they even know better than what the previous generation experienced.

In society, games may have a negative influence on children. On the other hand, games bring positive benefits for children; for instance, games introduce technology to children; children are used to following directions and obeying rules; children practice solving problems and using logic; games train children's motor nerves and spatial skills; and games establish communication between children and parents while playing together, and provide entertainment. Along with the development of the postmodern era, currently, children prefer Android-based games to toys. The development of this era also harms children regarding the knowledge of Indonesian/Nusantara arts, especially in music. Many of them do not understand that traditional musical instruments are not only limited to angklung (an Indonesian musical instrument consisting of two to four bamboo tubes 
suspended in a bamboo frame, bound with rattan cord) and kendang (two-headed drum).

With the advent of technology, children's interest in learning various Indonesian musical instruments has disappeared due to the rise of far more interesting Android-based games. This also has an impact on teachers and parents who want to introduce Nusantara musical instruments, where they find it difficult to find ways to facilitate the children to learn such knowledge to maintain Indonesian arts by generations.

With the coronavirus outbreak that requires everyone to work and carry out teaching and learning from home, school activities in Indonesia are temporarily conducted online using electronic media such as cell phones or laptops. The impact of the Covid-19 pandemic is that almost all children tends to get bored easily. Instead of playing with their toys, they turn to play games on their parents' cell phones, where there are various exciting games as their media to explore many new things.

This phenomenon makes parents and teachers rack their brains and think of ways to make children continue to study and focus even in the pandemic condition. Many teachers today have used technology for their teaching media. Therefore, in this current postmodern era, teachers employ technologies to develop learning media by making educational games.

Educational games are designed to teach users about developing conceptual understanding and training their abilities. Hurd \& Jenuings [6] conveyed that games should also motivate users to use it. Averagely, children like to play games that are easy to play and interesting. One of the simple games for children is a puzzle.

A puzzle is a game of arranging pictures previously shuffled. As a child-friendly play, playing puzzles has a lot of educational values. The level of difficulty in playing the puzzle is adjusted to age and child development. A simple puzzle consists of only four to six pieces. Meanwhile, complicated puzzles for children can reach six to sixteen pieces.

Therefore, the researchers made an innovation by making android-based puzzle games as learning media to introduce Indonesian musical instruments to children. The games present various pictures of traditional musical instruments arranged with attractive colors to enhance the learning engagement. In addition, children's motor skills can be practiced through Android-based puzzles.

Based on the facts and problems found by the researchers, they are interested in conducting research with the title of Android-Based Educational Games as
Media for Children to Learn Nusantara Musical Instruments.

\section{LITERATURE REVIEW}

\subsection{Android-Based Puzzles as Educational Games}

According to Leyton-Brown \& Shoham [8], game is a way of learning to analyze with a group of players and individuals using rational strategies. In some cases, games can also be used as a healing therapy [5]. According to Gargenta [3], Android is an open-source platform designed for mobile devices and provides all the tools and frameworks for developing mobile applications quickly and easily.

Ismail [7] states that educational games are fun activities played with or without tools to educate. Ernawati et al. [2] explain that puzzles are brain teasers searching and remembering the right words for answers in the available boxes.

\subsection{Learning Media}

Sadiman [9] explains that learning media is anything used to transmit messages from the sender to the recipient. In learning interactions, teachers present information in the form of learning materials to students.

\subsection{Nusantara Musical Instruments}

According to Tumbijo [10], the definition of traditional or Nusantara musical instruments is a cultural art that has been living and developing in certain areas for a long time as a heritage that must be preserved.

\section{RESEARCH METHOD}

This research employed an ADDIE development model consisting of five stages: the analysis, design, development, implementation, and evaluation.

The first procedure for the development was analysis. At this stage, the researchers analyzed the needs of children's (Age 3-6) learning methods that they are fond of, searched for any Nusantara musical instruments easily recognized by children, and hardware and software used to develop the media. Then, the second stage was design. At this stage, the researchers developed a media appropriateness assessment instrument and then made the storyboard, 
question items, and answer keys, background, pictures, and the menu buttons.

The third one was the development stage. After the researchers made the design, they submitted it to the media developer. The developer began to digitally visualize the storyboard, background, images, and the menu buttons. Then, the appropriateness was assessed by the material experts, media experts, and learning practitioners. The results were in the form of suggestions, comments, and inputs used to analyze and revise the media and conduct the product try-out. If the revision has been made and the product is claimed appropriate to try-out, the product will be implemented to the target in the fourth stage. The last was the evaluation stage. After the implementation stage, children's learning activities would be remeasured based on initial and final observations to determine the improvement of children's interest in learning activities before and after the media was applied.

\section{FINDINGS}

This study employed the ADDIE development model, which includes the Analysis, Design, Development, Implementation, and Evaluation stages. This is a learning design model based on an effective and efficient system approach and an interactive process, namely the evaluation results of each phase, which can bring the learning development to the next phase [1]. In developing this puzzle game application, the researchers referred to the following research framework:

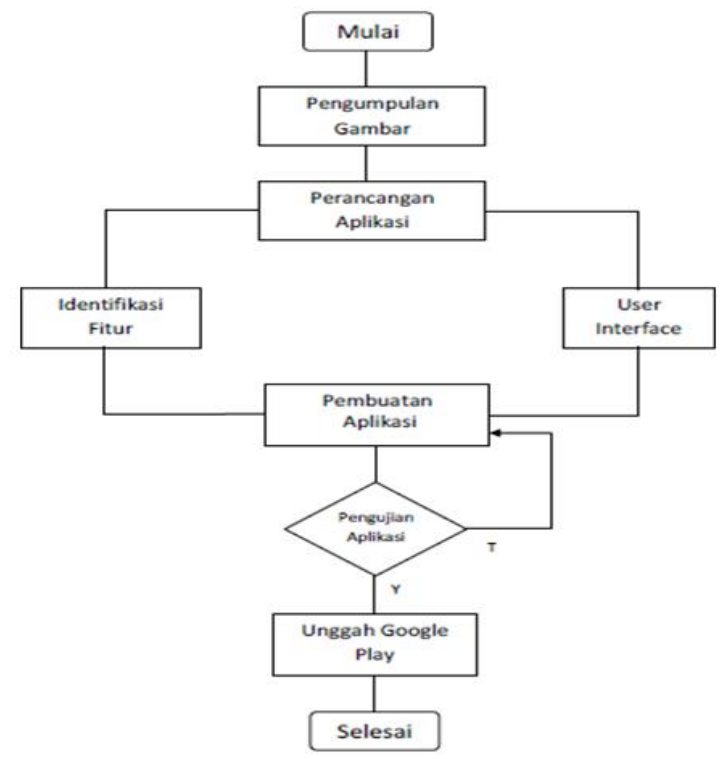

Figure 1 Research Framework
However, the android-based game development research was only conducted in the three stages, namely ADD (Analysis, Design, Development); thus, the media development process was only up to the development stage. The stages of developing the learning media, i.e., android-based puzzle games based on the ADD model for the introduction of Nusantara musical instruments, is explained as follows:

\subsection{Analysis}

At this stage, the researchers conducted an initial analysis, namely finding the character or nature of children by observing how they could understand a learning material in an easy but fun way. The aim was to identify children's learning needs; therefore, they were able to reach the maximum level of knowledge in learning. Based on the character analysis and observation in children with a range of 3-6 years, they prefer to study while playing. This is a fun activity for them to understand the material easier.

In addition, the researchers selected several kinds of traditional musical instruments that will be displayed and played in the puzzle game. The traditional musical instruments include Angklung from West Java Province, Kolintang from North Sulawesi Province, Sasando from East Nusa Tenggara Province, Kecapi from West Java Province, Tifa from Papua Province, Rebab from Special Capital Region of Jakarta and West Java Province.

Furthermore, the researchers also determined the hardware and software used to develop the Androidbased game. The media production hardware consisted of the ASUS X455L laptop with an Intel Core i34030U (1.9GHz) CPU processor, 2GB RAM, 500GB HDD, and Windows 10 OS. In addition, the software included a Mozilla Firefox browser and Appsgeyser application used to make the game.

\subsection{Design}

In this stage, the researcher made a storyboard of the media. It was completed with information that helped the developers to develop the Android-basedPuzzle Game application to introduce Nusantara Musical Instruments to children. 




Figure 2 Storyboard Outline

The storyboard outline description is as follows. There are four kinds of pages, including the first front page, which contains the title 'Puzzle Games to Learn Nusantara Musical Instruments'. The second page provides an option to start playing with the game rule. Third, there is a page to select which pictures to arrange in the puzzle. After the puzzle has been completed, the application will display an options page to exit the game.

The next stage was the development of question items and answer keys. In this stage, the researchers described the traditional musical instrument for each picture. The application used to draw the traditional musical instruments was Corel Draw X4. The following is an example of a traditional musical instrument (Angklung) design included in the puzzle games.

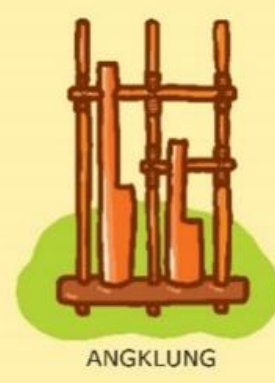

Figure 3 Traditional Musical Instrument (Angklung) from West Java

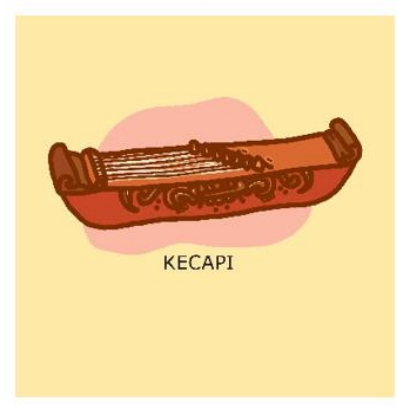

Figure 4 Traditional Musical Instrument (Kecapi) from West Java

The researchers collaborated with the developers to collect backgrounds, pictures, and menu buttons to support the learning media to be more attractive and easier to use. The researchers conveyed all the wanted and planned concepts, which were then visualized in a digital form by the developer.

\subsection{Development}

At this stage, the learning media was made based on the predetermined format using an ASUS X455L laptop with an Intel Core i3-4030U (1.9GHz) CPU processor, 2GB RAM, 500GB HDD, and Windows 10 OS. All the components were processed into a media unit using Mozilla Firefox software and made on the Appsgeyser website. The application was then saved in the APK file format (.apk) and ready to be installed on a smartphone with the Android operating system. The following is an example of the result.

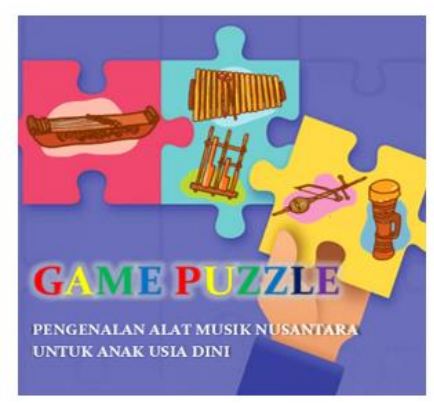

Figure 5 Puzzle Game Logo

Puzzle Game Logo: the logo was made using the Corel Draw X4 application and represented the Puzzle Game to learn Nusantara Musical Instruments. 


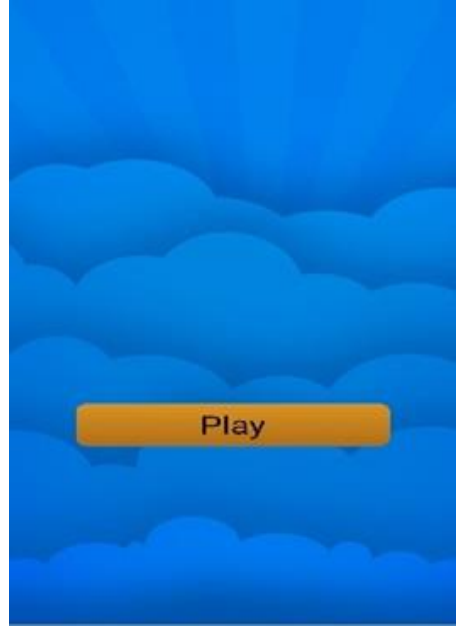

Figure 6 Front Page of Puzzle Game

Front Page of Puzzle Game: the frontpage represents the Puzzle Game to learn Nusantara Musical Instruments.

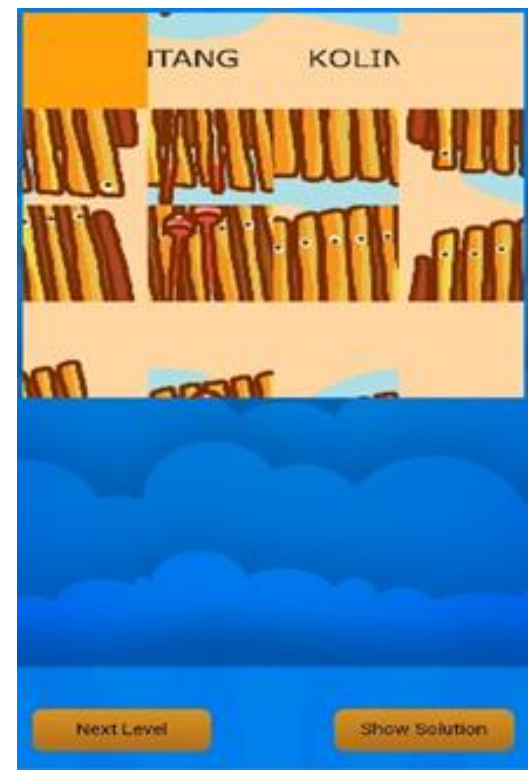

Figure 7 Kolintang Puzzle Game

Kolintang Puzzle Game: in this game, the player has to arrange a randomized puzzle by sliding the picture box to the right, left, up, or down to form the Kolintang musical instrument's original image.

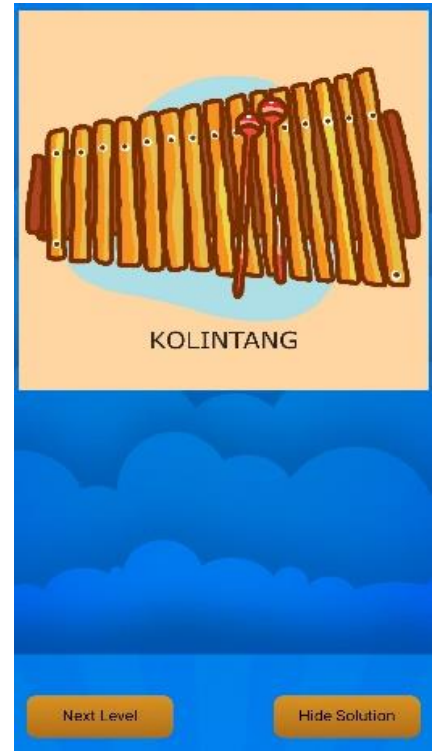

Figure 8 Show Solution in Kolintang Musical Instrument

Show Solution in Kolintang Musical Instrument: If the player feels that they need a clue, there is a menu button on the bottom right with the phrase 'show solution' containing a completed puzzle. Besides, the menu button on the bottom left shows the phrase 'next level' for the player who wants to try another puzzle picture.

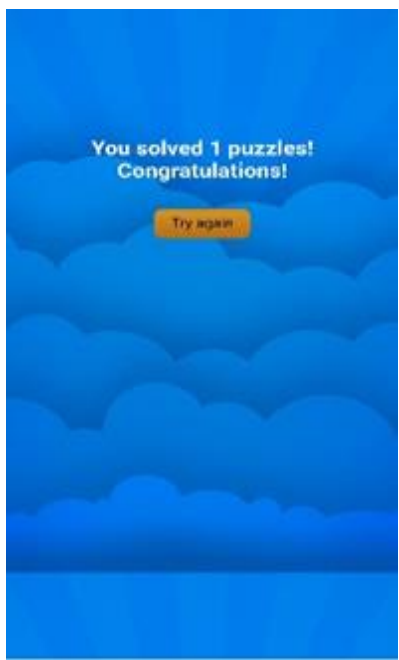

Figure 9 Game Score

Game score: When the player has completed all the puzzle levels, the score will appear.

This puzzle game application is still far from perfect; thus, a media and design validator is needed 
to revise what is still lacking or needs to be added so that the puzzle games are more accessible and more attractive for children to play. The media validator and design of the puzzle game application is Mr. Bayu Antrakusuma, M.Pd., founder of IT Consultant Phicos Group in Solo, Central Java.

The results of suggestions that need to be improved from the media validator and the design for media developers, namely the puzzle game application design, are still too basic. A background selection, musical instrument images, and cheerful music back sound are required to make it more attractive. As for the media's application, the puzzle should be a maximum of 9 boxes to make it easier for children to play. Besides, the addition of traditional musical instruments pictures examples so that the more puzzles are solved, the more complicated and challenging the next level is.

Currently, the process of developing Androidbased puzzle games to learn Nusantara Musical Instruments are still in the editing stage of application development from validator suggestions. Therefore, this game cannot be implemented and evaluated on the results of its implementation yet.

\section{CONCLUSIONS}

Research on Android-Based Educational Games as Media for Children to learn Nusantara Musical Instruments has successfully passed three out of five ADDIE development stages, including the Analysis, Design, and Development. Due to the postmodern era with the rapid development of technology and the phenomenon of online schools during the Covid-19 pandemic, the researchers developed Android-based learning media to improve the learning interest for children (3-6 years) to know and learn the Indonesian/Nusantara musical instruments through puzzles.

Although the Implementation and Evaluation stages have not been completed, the researchers realized that there are limitations in developing the learning media. To apply this method in the media development takes a long time; thus, some revisions are necessary to produce attractive and easy to play games played by children aged 3-6 years.

\section{REFERENCES}

[1] Branch, Robert Maribe. Implement. Instructional Design: The ADDIE Approach. Springer, Boston,
MA, $2009 . \quad 132-149 . \quad$ DOI: https://doi.org/10.1007/978-0-387-09506-6_5

[2] Ermaita, Ermaita, Pargito Pargito, and Pujiati Pujiati. Penggunaan Media Pembelajaran Crossword Puzzle untuk Meningkatkan Keterampilan Berpikir Kreatif Siswa [The Use of Crossword Puzzle as Learning Media to Improve Students' Creative Thinking Skills. Jurnal Studi Sosial 4.1 (2016): 41056.

[3] Gargenta, Marko. Learning android. O'Reilly Media, Inc., 2011.

[4] Hartati, Sofia. Perkembangan belajar pada anak usia dini [Learning development in early childhood]." Jakarta: Depdiknas (2005).

[5] Samuel, Henry. Cerdas Dengan Game: Panduan Praktis Bagi Orang Tua Dalam Mendampingi Anak Bermain Game [Smart Games With: A Practical Guide For Parents In Accompanying Children To Play Games]. Jakarta: Gramedia Pustaka Utama (2010).

[6] Hurd, Daniel, and Erin Jenuings. Standardized Educational Games Ratings: Suggested Criteria. Karya Tulis Ilmiah (2009).

[7] Ismail, Andang. Education games. Yogyakarta: Pro-U Media (2009).

[8] Leyton-Brown, Kevin, and Yoav Shoham. Essentials of game theory: A concise multidisciplinary introduction. Synthesis lectures on artificial intelligence and machine learning 2.1 (2008): 1-88. DOI: https://doi.org/10.1017/s0269888909990129

[9] Sadiman, Arief. Media Pendidikan (Pengertian, Pengembangan, Dan, Pemanfaatannya) [Media Education (Definition, Development, and, Utilization)]. Rajawali Pers, 2020.

[10] Tumbijo, H. B. Dt. 1977. Minangkabau Dalam Seputar Seni Tradisional [Minangkabau within Traditional Art]. Padang: SMSR N. Padang. 